Supporting Information for:

\title{
Cisplatin Prodrug-Loaded Nanoparticles Based on Physalis Mottle Virus for Cancer Therapy
}

$\mathrm{He} \mathrm{Hu}^{1}$ and Nicole F. Steinmetz ${ }^{1,2,3,4,5 *}$

${ }^{1}$ Department of NanoEngineering, ${ }^{2}$ Department of Bioengineering, ${ }^{3}$ Department of Radiology,

${ }^{4}$ Moores Cancer Center, and ${ }^{5}$ Center for Nano-ImmunoEngineering, University of California-San

Diego, La Jolla, California, 92093, United States.

*Email: nsteinmetz@ucsd.edu 


\section{CisPt(IV) Maleimide synthesis and characterization:}

\section{(Isobutyl carbonic) 3-(2,5-dioxo-2,5-dihydro-1H-pyrrol-1-yl)propanoic anhydride:}

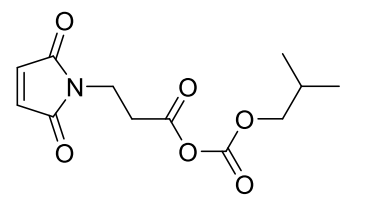

To a solution of maleimidopropanoic acid $(215 \mathrm{mg}, 0.80 \mathrm{mmol})$ in anh.

THF (2.0 mL) was added 4-methylmorpholine $(81 \mathrm{mg}, 88 \mu \mathrm{L}, 0.80 \mathrm{mmol})$.

The reaction was cooled to $0{ }^{\circ} \mathrm{C}$, and isobutylchloroformate $(109 \mathrm{mg}, 104 \mu \mathrm{L}, 0.80 \mathrm{mmol}$ ) was added to this solution dropwise. The reaction was gradually warmed to room temperature and stirred for $30 \mathrm{~min}$. Water $(10 \mathrm{~mL})$ was added to the reaction. The reaction mixture was extracted with EtOAc $(20 \mathrm{~mL} \times 3)$. The combined organic phase was dried over $\mathrm{MgSO}_{4}$. The solvents were removed under vacuum. A slightly brown oil was obtained (482 mg, 89\% yield). The product was used in the next step without further purification. ${ }^{1} \mathrm{H}$ NMR (400 MHz, $\left.\mathrm{CDCl}_{3}\right) \delta 6.72(\mathrm{~s}, 2 \mathrm{H}), 4.04$ (d, $J=6.7 \mathrm{~Hz}, 2 \mathrm{H}), 3.88(\mathrm{t}, J=7.1 \mathrm{~Hz}, 2 \mathrm{H}), 2.83(\mathrm{t}, J=7.1 \mathrm{~Hz}, 2 \mathrm{H}), 2.02$ (nonet, $J=6.7 \mathrm{~Hz}, 1 \mathrm{H}$ ), $0.96(\mathrm{~d}, J=6.8 \mathrm{~Hz}, 6 \mathrm{H}) \cdot{ }^{13} \mathrm{C}\left\{{ }^{1} \mathrm{H}\right\} \mathrm{NMR}\left(101 \mathrm{MHz}, \mathrm{CDCl}_{3}\right) \delta 170.25,165.37,148.73,134.43$, 75.90, 32.97, 32.83, 27.73, 18.88. EI-MS(+) $\mathrm{m} / \mathrm{z}$ calcd for $[\mathrm{M}+\mathrm{Na}]^{+} 292.1$, found 291.8. 


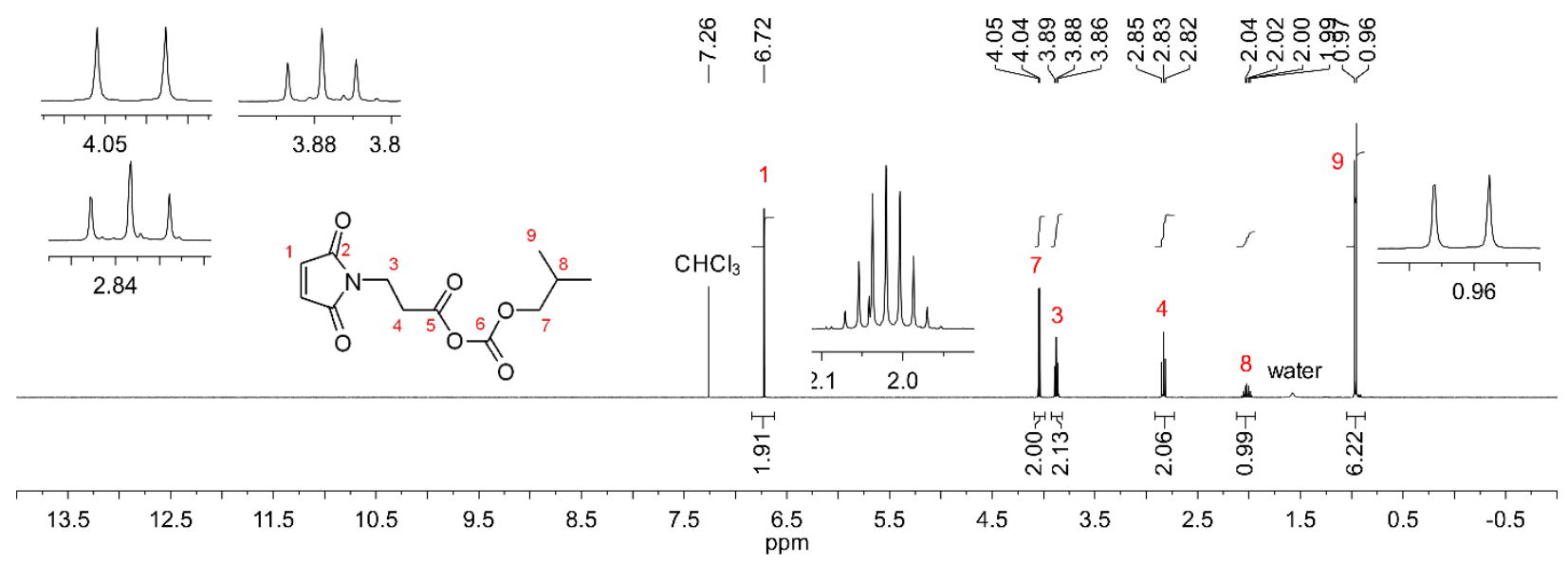

Figure S1. ${ }^{1} \mathrm{H}$ NMR spectrum of (isobutyl carbonic) 3-(2,5-dioxo-2,5-dihydro-1H-pyrrol-1yl)propanoic anhydride.

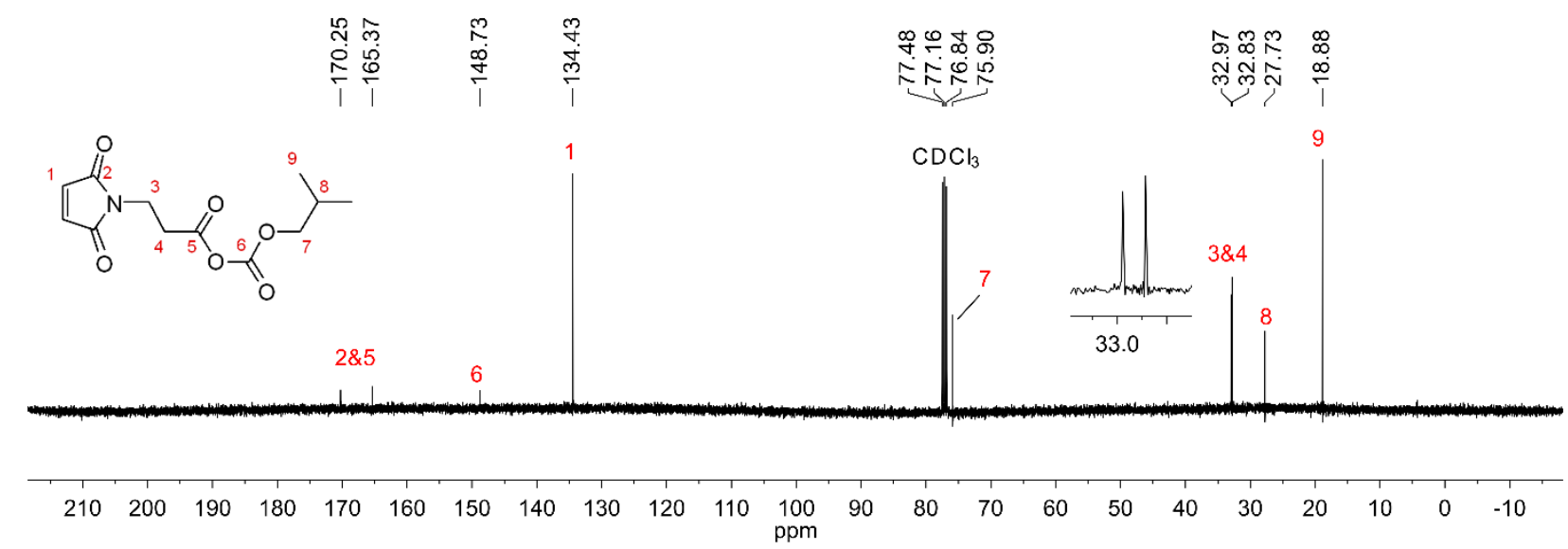

Figure S2. ${ }^{13} \mathrm{C}\left\{{ }^{1} \mathrm{H}\right\}$ NMR spectrum of (isobutyl carbonic) 3-(2,5-dioxo-2,5-dihydro-1H-pyrrol-1yl)propanoic anhydride. 


\section{cis,cis,trans-[Pt( $\left.\left.\mathrm{NH}_{3}\right)_{2} \mathrm{Cl}_{2}\left(\mathrm{O}_{2} \mathrm{CCH}_{2} \mathrm{CH}_{2} \mathrm{CO}-\mathrm{N} \text {-maleimide }\right)_{2}\right]$ :}

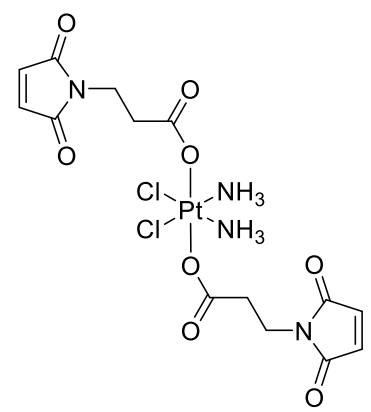

To a solution of (isobutyl carbonic) 3-(2,5-dioxo-2,5-dihydro-1H-pyrrol-1yl)propanoic anhydride $(269 \mathrm{mg}, 1.0 \mathrm{mmol})$ in anh. DMF $(5.0 \mathrm{~mL})$ was added cis,cis,trans-[Pt( $\left.\left.\mathrm{NH}_{3}\right)_{2} \mathrm{Cl}_{2}(\mathrm{OH})_{2}\right](84 \mathrm{mg}, 0.25 \mathrm{mmol})$. The reaction was stirred at $55^{\circ} \mathrm{C}$ for $48 \mathrm{~h}$. The reaction mixture was filtered through a $0.20 \mu \mathrm{m}$ PTFE syringe filter and diluted with water. The crude product was purified by HPLC using a C18 reverse stationary phase (Zorbax-SB C18 columns: $7 \mu \mathrm{m}, 21.2 \times 250 \mathrm{~mm}$ ) and a mobile phase composed of two solvents $\left(\mathrm{A}: \mathrm{H}_{2} \mathrm{O}+0.1 \%(\mathrm{v} / \mathrm{v}) \mathrm{CF}_{3} \mathrm{CO}_{2} \mathrm{H}\right.$; B: $\left.\mathrm{CH}_{3} \mathrm{CN}+0.1 \%(\mathrm{v} / \mathrm{v}) \mathrm{CF}_{3} \mathrm{CO}_{2} \mathrm{H}\right)$. The following gradient was used: $0-3$ min, solvent $\mathrm{B}=10 \%-22 \% ; 3-9$ min, solvent $\mathrm{B}=22 \%-28 \% ; 9-$ 12 min, solvent $\mathrm{B}=28 \%-100 \% ; 12-15 \mathrm{~min}$, solvent $\mathrm{B}=100 \%-10 \% ; 15-16$ min, solvent $\mathrm{B}=10 \%$. To remove the residual $\mathrm{CF}_{3} \mathrm{CO}_{2} \mathrm{H}$, the combined product was lyophilized and passed through a Biotage $\mathrm{C} 18$ reverse phase column using a mobile phase composed of two solvents $\left(\mathrm{A}: \mathrm{H}_{2} \mathrm{O}+0.1 \%(\mathrm{v} / \mathrm{v}) \mathrm{CH}_{3} \mathrm{CO}_{2} \mathrm{H}\right.$; $\mathrm{B}$ : $\left.\mathrm{CH}_{3} \mathrm{CN}+0.1 \%(\mathrm{v} / \mathrm{v}) \mathrm{CH}_{3} \mathrm{CO}_{2} \mathrm{H}\right)$ using a linear gradient of solvent $\mathrm{B}$ from $0 \%$ to $40 \%$. The purified product was lyophilized to give a slightly brown solid (41 mg, 26\% yield). The purity of the product was assessed by analytical HPLC using a C18 reverse stationary phase (Zorbax-SB C18 columns: $5 \mu \mathrm{m}, 4.6 \times 250 \mathrm{~mm}$ ) and a mobile phase composed of two solvents $\left(\mathrm{A}: \mathrm{H}_{2} \mathrm{O}+0.1 \%(\mathrm{v} / \mathrm{v}) \mathrm{CF}_{3} \mathrm{CO}_{2} \mathrm{H} ; \mathrm{B}: \mathrm{CH}_{3} \mathrm{CN}+0.1 \%\right.$ (v/v) $\left.\mathrm{CF}_{3} \mathrm{CO}_{2} \mathrm{H}\right)$. The following gradient was used: $0-5 \mathrm{~min}$, solvent $\mathrm{B}=10 \% ; 5-30 \mathrm{~min}$, solvent $\mathrm{B}=10 \%-$ $100 \% ; 30-33$ min, solvent $\mathrm{B}=100 \% ; 33-36 \mathrm{~min}$, solvent $\mathrm{B}=100 \%-10 \% ; 36-40$ min, solvent $\mathrm{B}=$ $10 \% . \mathrm{T}_{\mathrm{R}}=14.3 \mathrm{~min} .{ }^{1} \mathrm{H}$ NMR $\left(500 \mathrm{MHz}\right.$, Acetone- $\left.d_{6}\right) \delta 6.85(\mathrm{~s}, 4 \mathrm{H}), 6.57-6.04(\mathrm{~m}, 6 \mathrm{H}), 3.68(\mathrm{t}, J=7.1$ $\mathrm{Hz}, 4 \mathrm{H}), 2.50(\mathrm{t}, J=7.1 \mathrm{~Hz}, 4 \mathrm{H}) .{ }^{195} \mathrm{Pt} \mathrm{NMR}\left(108 \mathrm{MHz}\right.$, Acetone- $\left.d_{6}\right) \delta 1118 .{ }^{13} \mathrm{C}$ NMR $(126 \mathrm{MHz}$, Acetone$\left.d_{6}\right) \delta 180.14(\mathrm{~m}), 171.82,135.25,35.91,35.29 . \mathrm{MS}(\mathrm{ESI}+): \mathrm{m} / \mathrm{z}$ calcd for $[\mathrm{M}+\mathrm{H}]^{+} 636.0$, found 636.8. MS (ESI-): $\mathrm{m} / \mathrm{z}$ calcd for $[\mathrm{M}-\mathrm{H}]^{-}$634.0, found 634.6. 


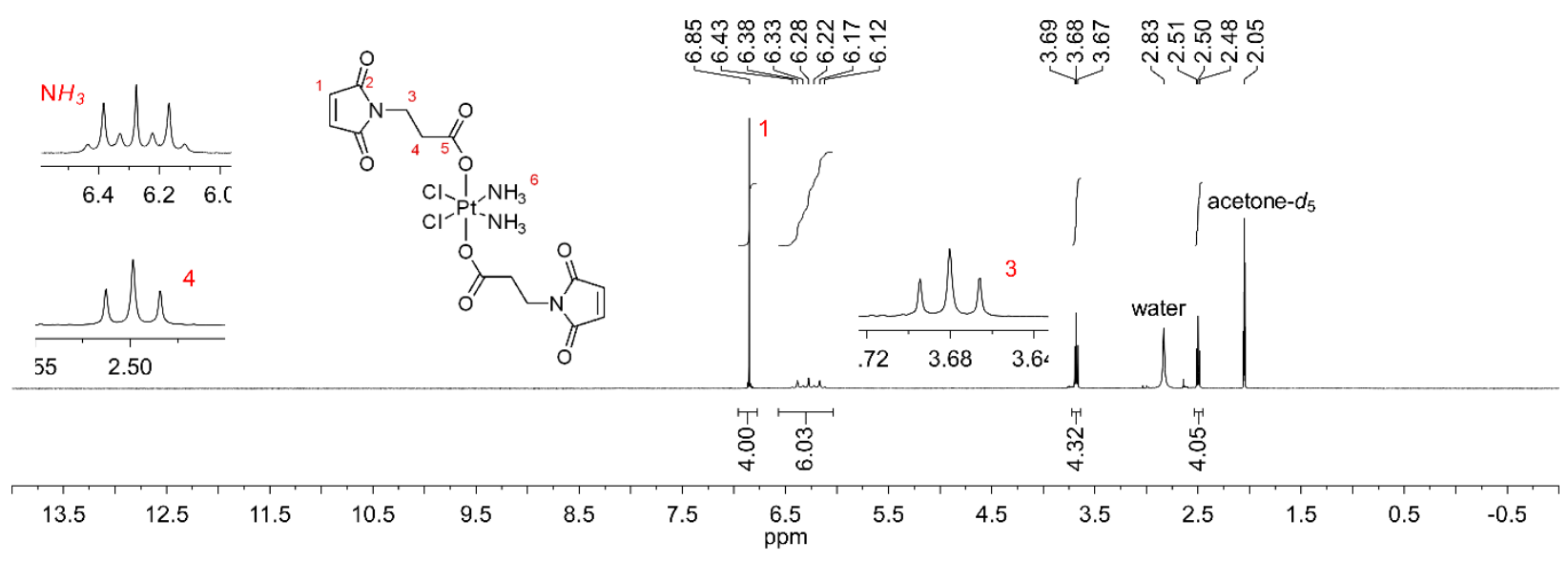

Figure S3. ${ }^{1} \mathrm{H}$ NMR spectrum of cis, cis, trans- $\left[\mathrm{Pt}\left(\mathrm{NH}_{3}\right)_{2} \mathrm{Cl}_{2}\left(\mathrm{O}_{2} \mathrm{CCH}_{2} \mathrm{CH}_{2} \mathrm{CO}-N \text {-maleimide }\right)_{2}\right]$.

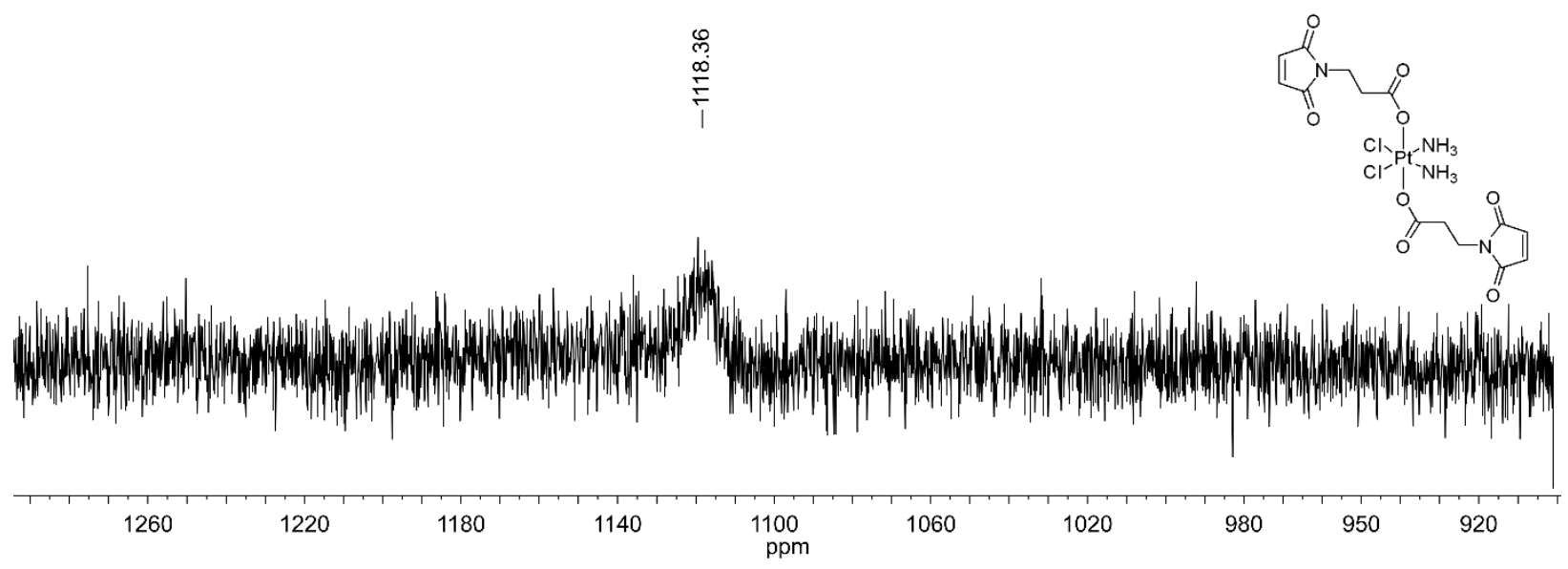

Figure S4. ${ }^{195} \mathrm{Pt} \mathrm{NMR}$ spectrum of cis, cis, trans- $\left[\mathrm{Pt}\left(\mathrm{NH}_{3}\right)_{2} \mathrm{Cl}_{2}\left(\mathrm{O}_{2} \mathrm{CCH}_{2} \mathrm{CH}_{2} \mathrm{CO}-N \text {-maleimide }\right)_{2}\right]$. 


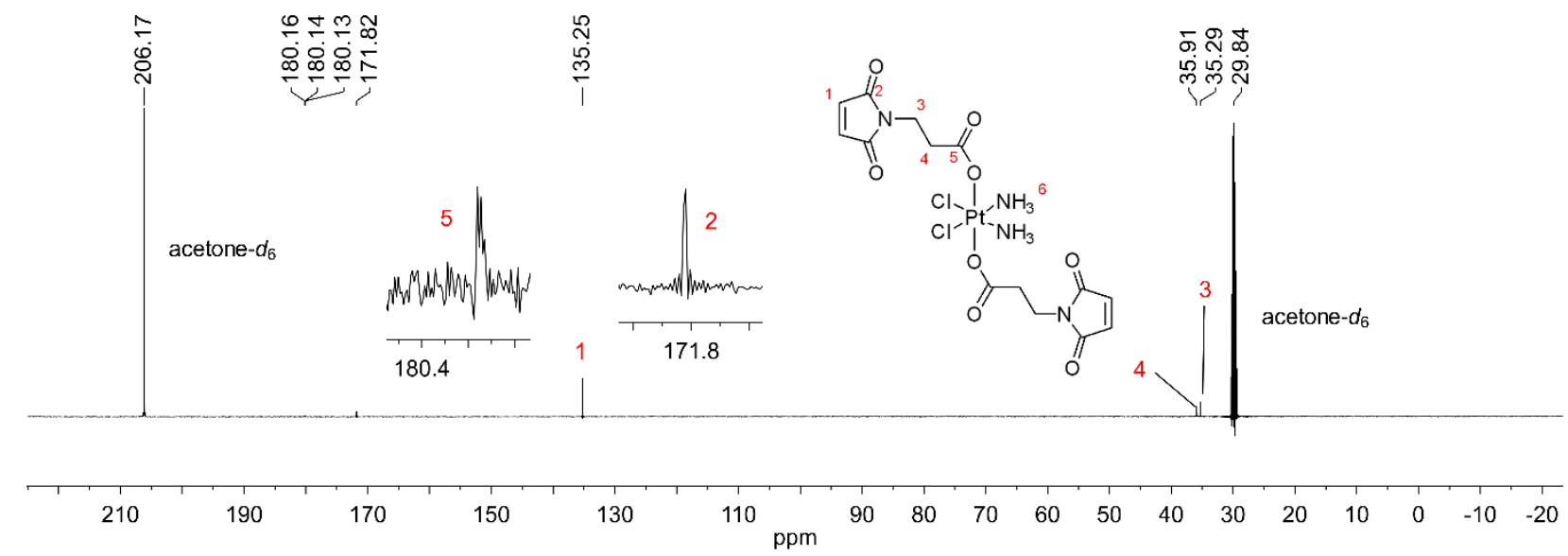

Figure S5. ${ }^{13} \mathrm{C}\left\{{ }^{1} \mathrm{H}\right\} \quad \mathrm{NMR}$ spectrum of cis,cis, trans- $\left[\mathrm{Pt}\left(\mathrm{NH}_{3}\right)_{2} \mathrm{Cl}_{2}\left(\mathrm{O}_{2} \mathrm{CCH}_{2} \mathrm{CH}_{2} \mathrm{CO}-N-\right.\right.$ maleimide) 2 .
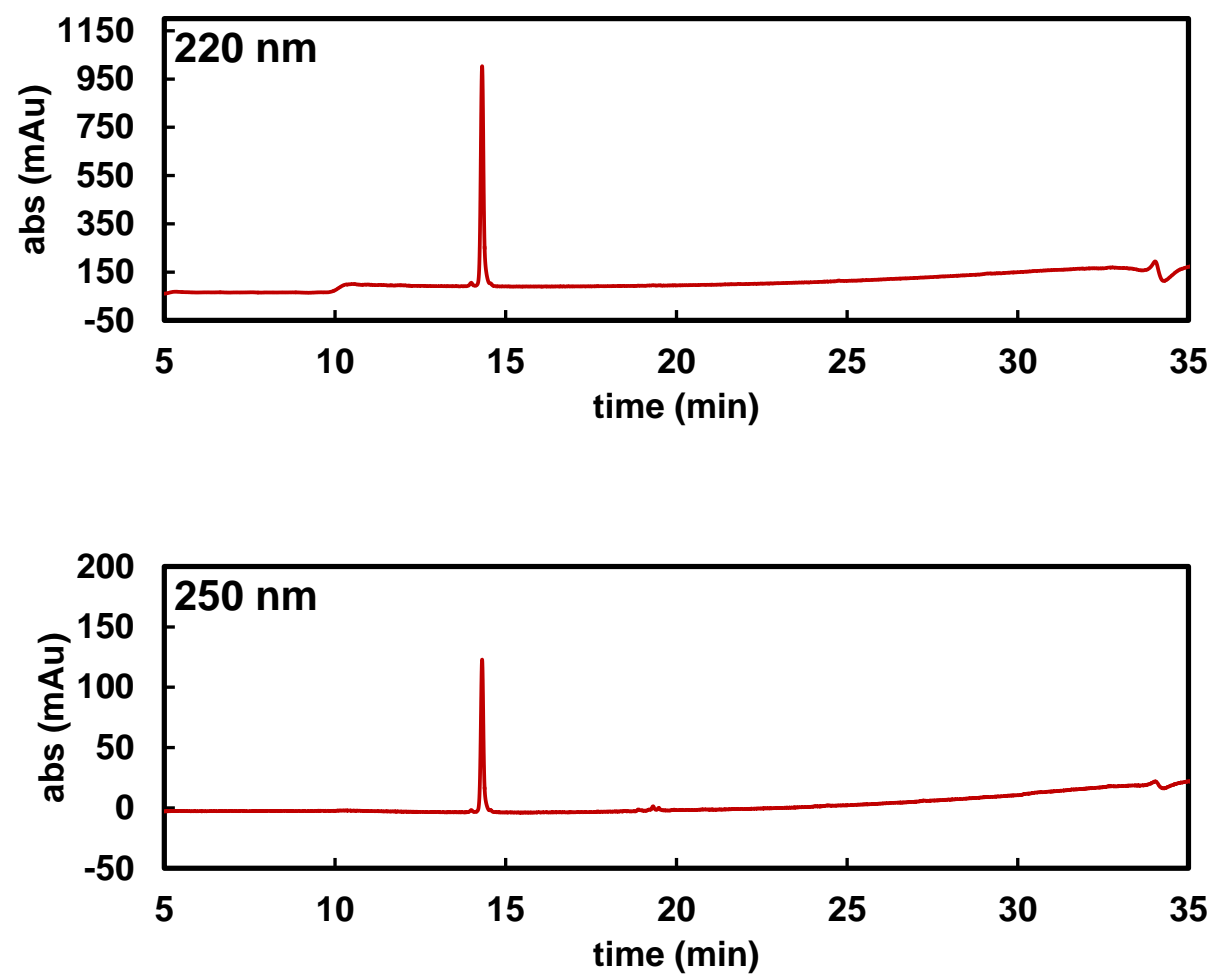

Figure S6. Analytical HPLC chromatogram of cis,cis, trans- $\left[\mathrm{Pt}\left(\mathrm{NH}_{3}\right)_{2} \mathrm{Cl}_{2}\left(\mathrm{O}_{2} \mathrm{CCH}_{2} \mathrm{CH}_{2} \mathrm{CO}-N-\right.\right.$ maleimide) 2 . Absorbance monitored at $220 \mathrm{~nm}$ (top) and $250 \mathrm{~nm}$ (bottom). 


\section{Characterization methods:}

UV/vis spectroscopy: The protein concentration in the nanoparticle formulations was determined using the Pierce BCA protein quantitation assay kit (Thermo Fisher Scientific). The dye load was determined by measuring UV/vis absorbance on a NanoDrop 2000 spectrophotometer (Thermo Fisher Scientific) and using the protein concentration combined with the Beer-Lambert law and the dye-specific extinction coefficient for Cy5.5-maleimide of $\varepsilon(673 \mathrm{~nm})=209,000 \mathrm{M}^{-1} \mathrm{~cm}^{-1}$.

Native and denaturing gel electrophoresis: Native and modified VLPs were analyzed by 1\% (w/v) agarose native gel electrophoresis (10-20 $\mu \mathrm{g}$ per lane) in 0.1 M Tris-maleate running buffer (pH 6.5). Denatured protein subunits (10 $\mu$ g per lane) were analyzed by SDS-PAGE using 4-12\% NuPAGE gels in 1x MOPS buffer (Thermo Fisher Scientific). Samples were denatured by boiling in SDS loading dye for $10 \mathrm{~min}$. Gels were photographed under UV or white light before staining with Coomassie Brilliant Blue, and under white light after staining, using an AlphaImager system (ProteinSimple, Santa Clara, CA, USA).

Size exclusion chromatography: Native and modified VLPs were analyzed by SEC using the AkTA Explorer system fitted with a Superose-6 column (GE Healthcare, Chicago, IL, USA). The column was loaded with $100-\mu \mathrm{L}$ samples $(1 \mathrm{mg} / \mathrm{mL})$ at a flow rate of $0.5 \mathrm{~mL} / \mathrm{min}$ in $\mathrm{KP}$ buffer. Absorbance was measured at 260 and $280 \mathrm{~nm}$, and the Cy5.5 dye was monitored at $673 \mathrm{~nm}$.

Transmission electron microscopy: Native and modified VLPs $(1 \mathrm{mg} / \mathrm{mL})$ were suspended in 20 $\mu \mathrm{L}$ KP buffer and deposited onto Formvar carbon-coated copper TEM grids (Electron Microscopy 
Sciences, Hatfield, PA, USA) for 2 min at room temperature. The grids were then washed twice with deionized water for $45 \mathrm{~s}$ and stained twice with $2 \%(\mathrm{w} / \mathrm{v})$ uranyl acetate in deionized water for another $30 \mathrm{~s}$. A Tecnai F30 transmission electron microscope was used to analyze the samples at $300 \mathrm{kV}$.

Laser scanning confocal microscopy: Cell lines were grown for $24 \mathrm{~h}$ on glass coverslips $(25,000$ cells per well) in an untreated 24-well plate in $200 \mu \mathrm{L}$ of the appropriate medium. The cells were washed twice with Dulbecco's PBS (DPBS) before adding the VLPs at a final concentration of $\sim 2$ $\mu \mathrm{g} / \mathrm{mL}$ normalized to native PhMV particles (equivalent to $2 \times 10^{6} \mathrm{PhMV}$ particles per cell) and incubating for $3 \mathrm{~h}$. The cells were washed twice in DPBS to remove unbound particles and fixed for $5 \mathrm{~min}$ at room temperature in DPBS containing 4\% (v/v) paraformaldehyde and $0.3 \%(\mathrm{v} / \mathrm{v})$ glutaraldehyde. Cell membranes were stained with $1 \mu \mathrm{g} / \mathrm{mL}$ wheat germ agglutinin conjugated to AlexaFluor-555 (Invitrogen. Thermo Fisher Scientific) diluted 1:1000 in DPBS containing 5\% $(\mathrm{v} / \mathrm{v})$ goat serum, and the cells were then incubated for $45 \mathrm{~min}$ at room temperature in the dark. Finally, the cells were washed three times with DPBS, and the coverslips were mounted on glass slides using Fluroshield with 4',6-diamidino-2-phenylindole (DAPI; Sigma-Aldrich, St Louis, MO, USA) and sealed using nail polish. Confocal images were captured on a Nikon A1R confocal microscope and the images were processed using Nikon A1R confocal microscope workstation (Nikon, Tokyo, Japan).

Zeta potential analysis: The zeta potential $(\zeta)$ of the VLPs was determined by placing 0.25 $\mathrm{mg} / \mathrm{mL}$ solutions of each VLP in a 90Plus Zeta potential analyzer (Brookhaven Instruments) and conducting five measurements, each comprising six runs. 


\section{Supporting Data:}
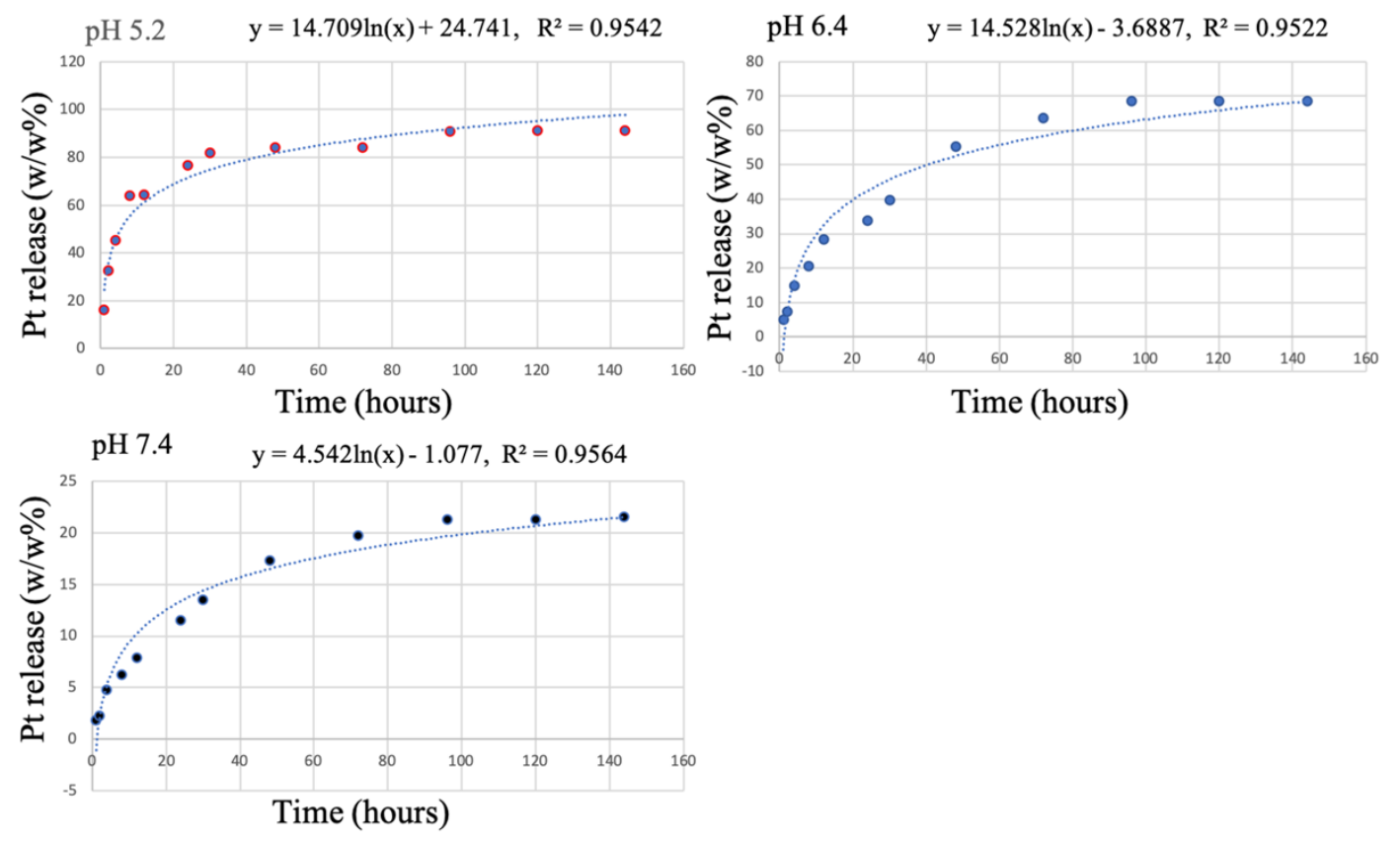

Figure S7. The logarithmic increment fitting of the kinetics of $\mathrm{Pt}(\mathrm{IV})$ reduced to $\mathrm{Pt}(\mathrm{II})$ at different $\mathrm{pH}$. 


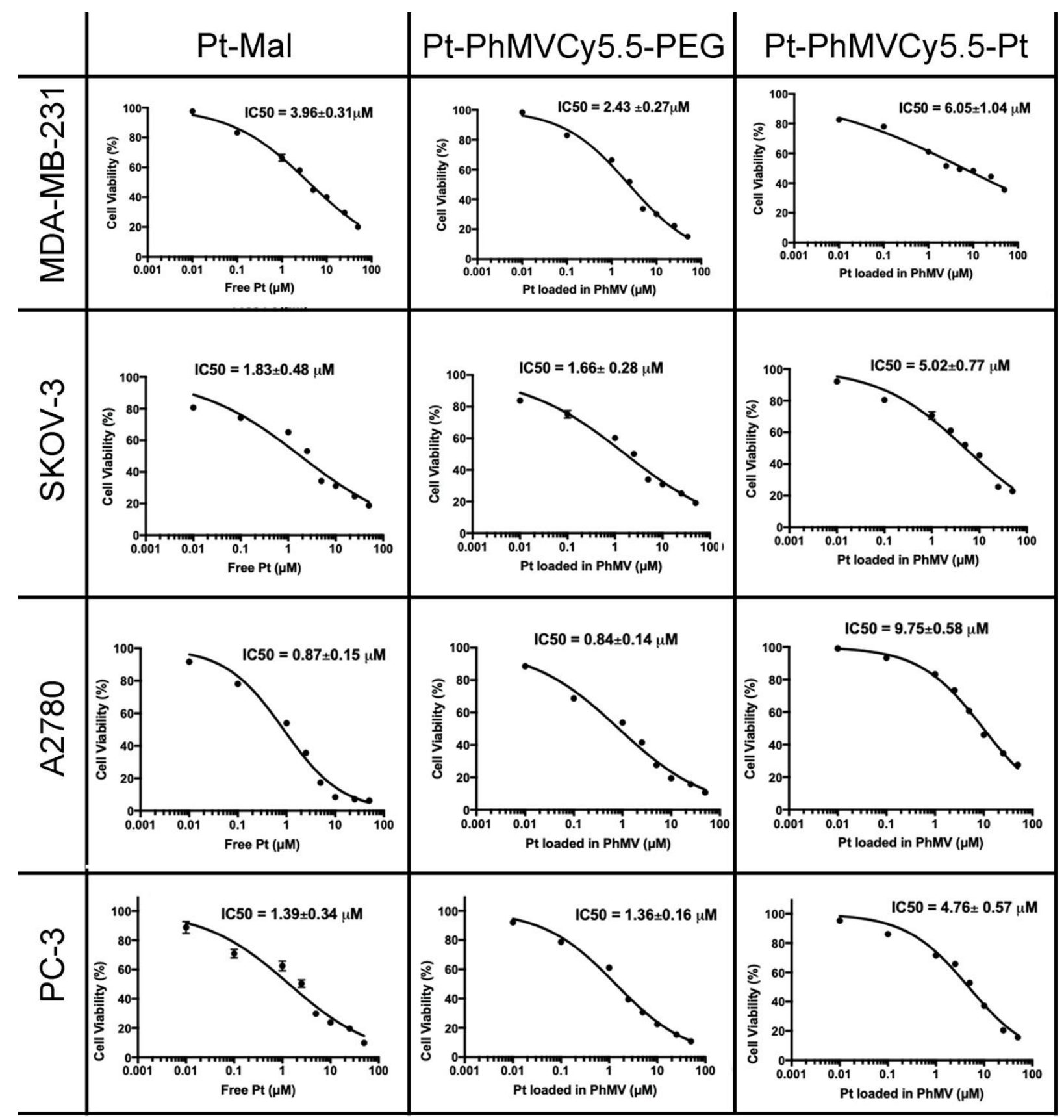

Figure S8. The $\mathrm{IC}_{50}$ profiles of free cisplatin, Pt-Mal, and Pt-loaded VLPs against a panel of cancer cells. Data from triplet experiments and standard deviations are shown. 


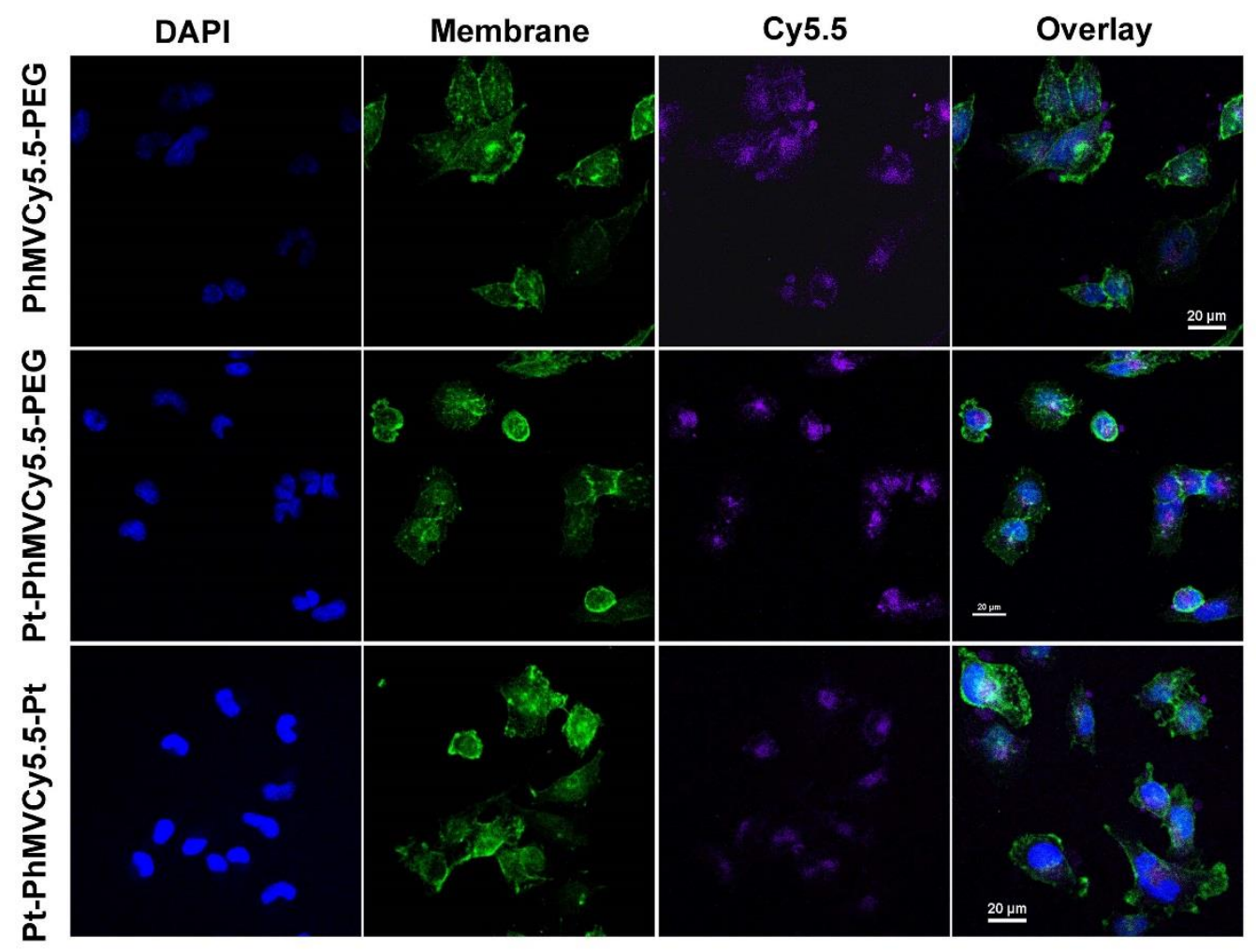

Figure S9. Cell trafficking of PhMV within MDA-MB-231 cells after $3 \mathrm{~h}$ incubation at the particle concentration of $10 \mu \mathrm{g} / \mathrm{mL}$ by confocal laser scanning microscopy (CLSM) (nuclei stained with DAPI in blue, membrane stained with A555-labeled wheat germ agglutinin in green, PhMV conjugated with Cy5.5 in purple, with scale bar $=20 \mu \mathrm{m})$. 


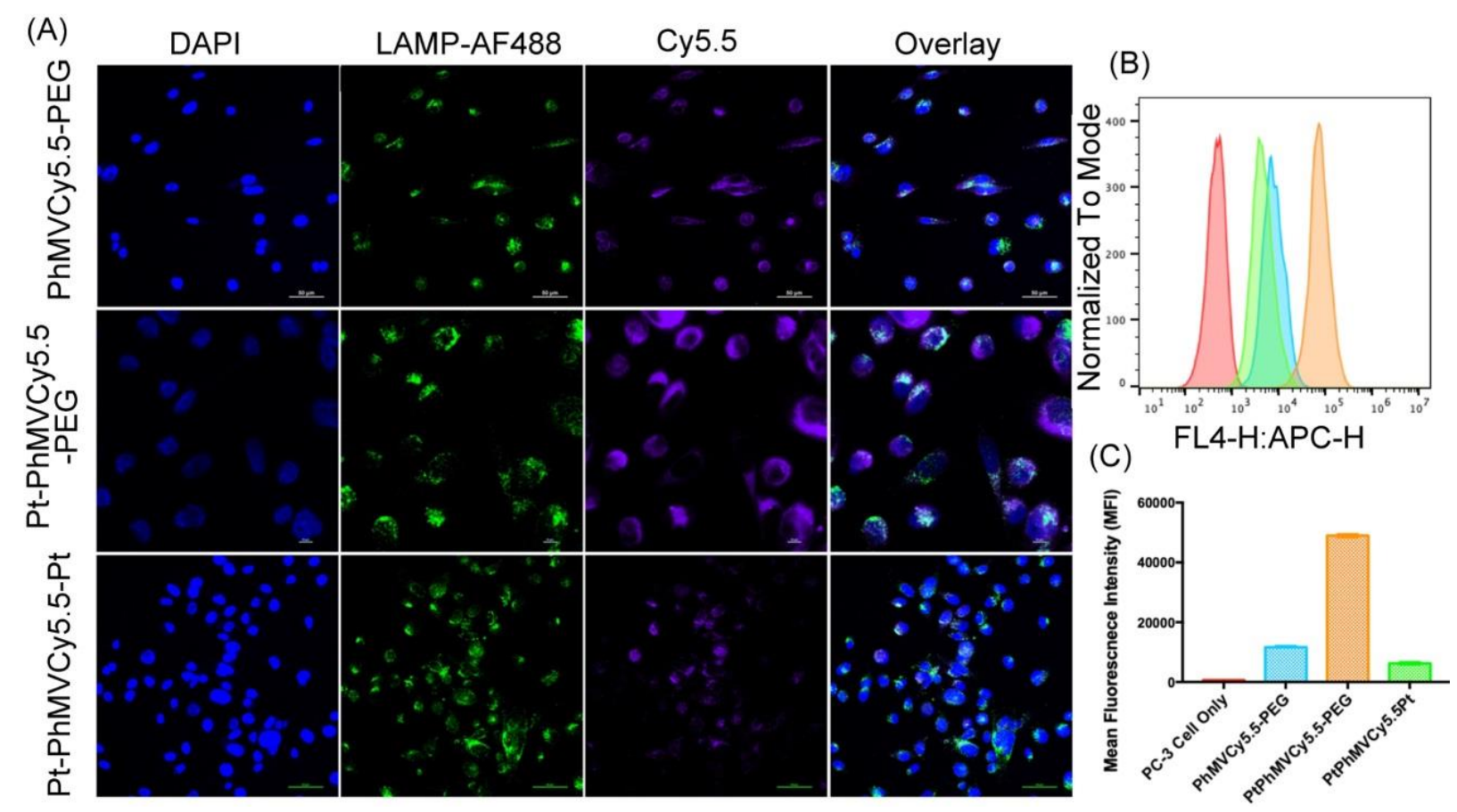

Figure S10. Analysis of VLP uptake and intracellular distribution by PC-3 cells. (A) Trafficking of PhMV-derived VLPs in PC-3 cells after incubation with $10 \mu \mathrm{g} / \mathrm{mL}$ VLPs for $3 \mathrm{~h}$, observed by confocal laser scanning microscopy. Nuclei are stained with DAPI (blue), membranes are stained with A555-labeled wheat germ agglutinin (green) and Cy5.5 conjugated to the VLPs is shown in purple. Scale bar $=20 \mu \mathrm{m}$. (B) Quantitative analysis by flow cytometry and (C) mean fluorescence intensities (MFIs) of cells in each sample $(n=3 \pm$ standard deviations, $p<0.001$ using Student's T-test). Data were analyzed using FlowJo v10. 

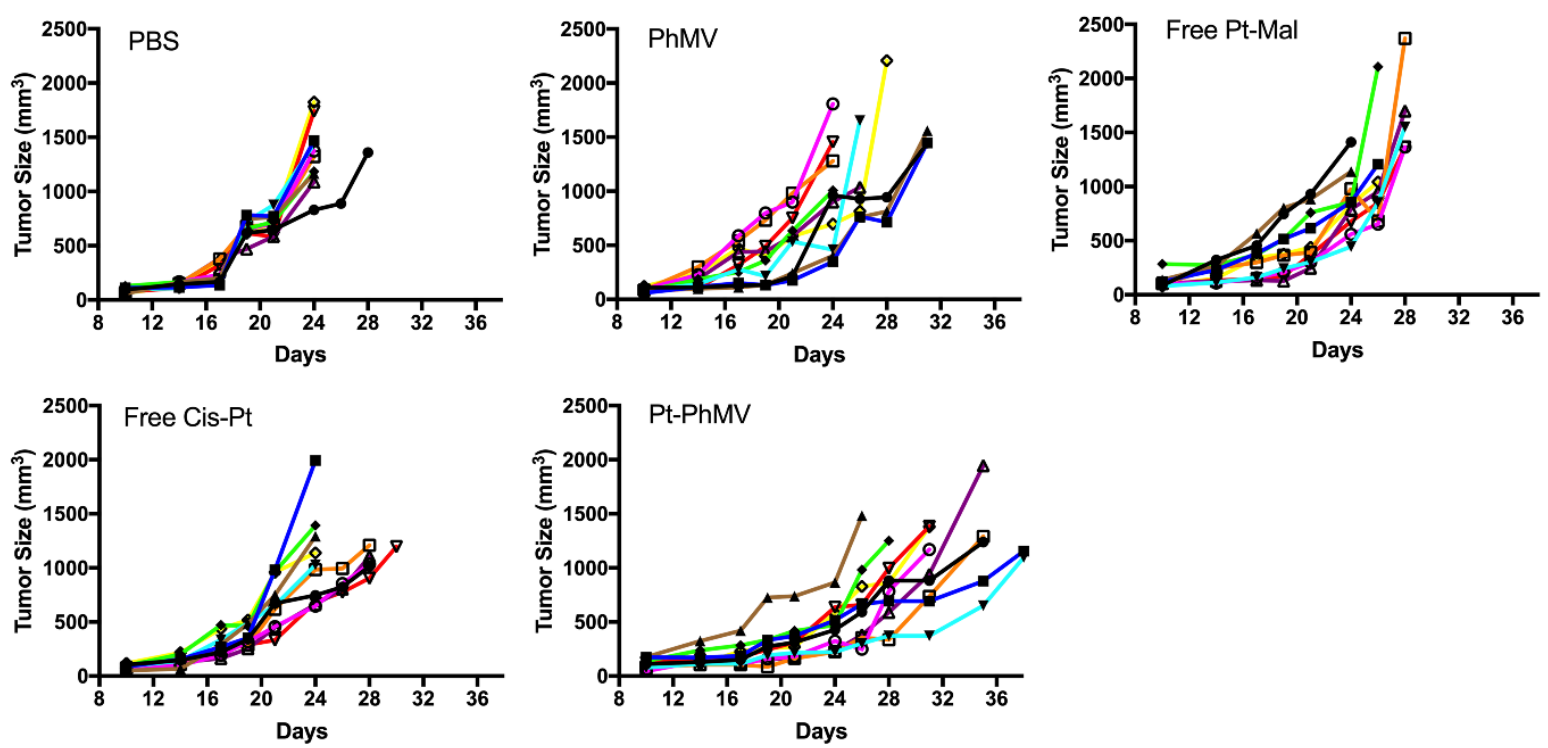

Figure S11. Inhibition of tumor growth in an athymic mouse model $(\mathrm{n}=10)$ with MDA-MB-231 xenografts after treatment with different formulations. The treatment began when tumors reached a volume of $\sim 150 \mathrm{~mm}^{3}$ and involved a twice-weekly intravenous bolus of $1.0 \mathrm{mg} \mathrm{Pt} / \mathrm{kg}$ in the form of cisplatin (cis-Pt), Pt-Mal or Pt-PhMVCy5.5-PEG (Pt-PhMV). PBS or PhMVCy5.5-PEG (PhMV) particles were administered as controls, with PhMVCy5.5-PEG particle dosage normalized to Pt-PhMVCy5.5-PEG. Tumor volumes and body weight were measured before each injection. Tumor growth curves of individual mice in each group. 